\title{
IMPLEMENTASI TEORI GENETIK EPISTEMOLOGY DALAM PEMBELAJARAN GUNA MEMANTAPKAN PERKEMBANGAN KOGNITIF ANAK USIA SEKOLAH
}

(Perspektif Konstruktivisme Terhadap Kultur Pendidikan Anak yang Mengakomodasi)

\section{Agust Ufie}

Dosen Prodi Pendidikan Sejarah - FKIP Universitas Pattimura

e-mail: ufieagust@yahoo.co.id

\section{ARTICLE INFO}

Article History:

Accepted 09 Maret 2017

Available online 10 April 2017

Keywords:

Piaget, Teori Genetik

Epistemology.

\begin{abstract}
Keberhasilan proses belajar mengajar tercermin dalam peningkatan hasil belajar, dan untuk mencapai hasil belajar dibutuhkan peran aktif seluruh komponen pendidikan, terutama siswa yang berperan sebagai input sekaligus sebagai output, serta guru sebagai fasilitator. Dengan demikian maka guru sangat diharapkan dapat memahami perkembangan peserta didik sesuai dengan tingkatan perkembangan pengetahuan mereka sebagaimana yang dikembangkan oleh Jean Piaget dalam teori Genetik Epistemology. Oleh karena itu, maka teori dalam ilmu pengetahuan pada hakikatnya adalah seperangkat konsep yang saling terkait yang digunakan untuk menjelaskan sekumpulan data untuk membuat prediksi tentang hasil dari suatu kegiatan eksperimen di masa depan. Berkaitan dengan hal tersebut, maka pengenalan secara utuh teori Genetik Epistemology dapat membantu guru dalam mengembangkan pembelajaran yang lebih berpihak pada siswa dan dapat disesuaikan dengan tingkat kognitif setiap siswa.
\end{abstract}

\section{PENDAHULUAN}

Perkembangan Ilmu Pengetahuan dan Teknologi terus bergerak maju, hal ini tentu membawa dampak di berbagai bidang kehidupan manusia. Untuk itu, mutlak diperlukan sumber daya manusia (SDM) yang berkualitas dan kompeten guna 
menguasai serta dapat mengendalikan kemajuan Ilmu Pengetahuan dan Teknologi, serta mampu menghadapi tantangan globalisasi. Pendidikan adalah salah satu sarana untuk mempersiapkan Sumber Daya Manusia yang berkualitas guna memenuhi keinginan kemajuan Ilmu Pengetahuan dimaksud. Dengan demikian maka secara umum ada hubungan erat antara kemajuan Ilmu Pengetahuan dan Teknologi dan peningkatan mutu pendidikan.

Dalam UU No. 20 Tahun 2003 tentang Sistem Pendidikan Nasional, disebutkan bahwa Pendidikan adalah usaha sadar dan terencana untuk mewujudkan suasana belajar dan proses pembelajaran agar peserta didik secara aktif mengembangkan potensi dirinya untuk memiliki kekuatan spiritual keagamaan, pengendalian diri, kepribadian, kecerdasan, akhlak mulia, serta keterampilan yang diperlukan dirinya, masyarakat, bangsa dan Negara. Olehnya itu, Pendidikan Nasional berfungsi mengembangkan kemampuan serta membentuk watak dan peradaban bangsa yang bermanfaat dalam rangka mencerdaskan kehidupan bangsa, bertujuan untuk mengembangkan potensi peserta didik agar menjadi manusia yang beriman dan bertakwa kepada Tuhan Yang Maha Esa, berakhlak yang demokratis, dan bertanggung jawab.

Pendidikan sangat penting bagi kehidupan dan tidak dapat dipisahkan dari kehidupan keluarga, masyarakat, maupun negara. Bahkan maju mundurnya suatu bangsa, dapat diukur dari kualitas pendidikan bangsa tersebut. Dewasa ini dalam proses pembangunan bangsa dan negara, Pendidikan mendapat perhatian yang serius. Hal tersebut nyata dari usaha pemerintah untuk terus meningkatkan mutu pendidikan dari berbagai jenjang. Hal ini tertuang dalam Garis-Garis Besar Haluan Negara (GBHN), sebagai berikut :

Pendidikan nasional yang bertujuan mencerdaskan kehidupan Bangsa diselenggarakan secara terpadu, dan diarahkan pada peningkatan kualitas Pendidikan dasar serta Pendidikan kejuruan. Dengan memperhatikan perkembangan ilmu pengetahuan dan teknologi (GBHN 1993, Kurikulum Pendidikan Dasar).

Guru merupakan komponen paling menentukan dalam sistem pendidikan secara keseluruhan yang harus dapat perhatian yang utama. Guru memegang peranan utama dan berbagai tugas dan tanggung jawab. Guru memegang peran utama dalam pembangunan pendidikan, khususnya yang diselenggarakan secara formal di sekolah. Guru juga merupakan salah satu faktor penentu keberhasilan peserta didik terutama dalam proses pembagian tugas, dan tanggung jawab guru adalah sebagai pengajar, pembimbing, dan administrator. Selain itu tugas dan tanggung jawab guru mencakup bidang pengajaran, bimbingan, pembinaan hubungan dengan masyarakat, 
pengembangan kurikulum, dan pengembangan profesi, Sugeng dalam Mutiah (2010 : 3). Tugas utama dan terpenting yang menjadi tanggung jawab guru adalah merangsang dan membimbing proses belajar siswa, sehingga nantinya akan tercapai suatu masyarakat yang modern yang dicita-citakan bangsa. Seperti telah disebutkan sebelumnya bahwa guru merupakan aktor utama dalam proses pembelajaran. Pembelajaran memiliki peranan penting dalam dunia pendidikan yaitu untuk menambah ilmu pengetahuan, keterampilan serta penerapan konsep diri. Menurut Setyosari (2011: 3 ) proses pembelajaran adalah kegiatan yang integral (terpadu) yang bertujuan untuk menciptakan kondisi supaya siswa dapat belajar dengan baik.

\section{METODE}

Untuk menganalisis kajian ini, penulis menggunakan teknik literatur review. Literatur Review adalah uraian tentang teori, temuan dan bahan penelitian lain yang diperoleh dari bahan acuan untuk dijadikan landasan kegiatan penelitian untuk menyusun kerangka pemikiran yang jelas dari perumusan masalah yang ingin diteliti. Tujuan akhir literatur review adalah untuk mendapatkan gambaran yang berkenaan dengan apa yang sudah pernah dikerjakan orang lain sebelumnya, (Creswell, 2010).

\section{Mengenal “Jean Piaget" Pencetus Teori “Genetik Epistemology"}

Penyair Noah Perry (dalam John W. Santrock, 2008: 46) pernah bertanya "Siapa yang tahu pikiran anak-anak" Psikolog Swiss Jean Piaget (1896-1980) tahu lebih banyak ketimbang orang lain. Penegasan tersebut menghantarkan kita kepada apa yang sesungguhnya berkembang saat ini, terutama meningkatnya minat orang terhadap teori genetic epistemology yang telah mengangkat status Piaget sebagai seorang ilmuan besar dan terus dikenang karena karya-karyanya dalam dunia pendidikan terutama perhatianya kepada perkembangan anak-anak. Siapa Jean Piaget dan bagaimana jejaknya, Jean Piaget lahir pada tanggal 9 Agustus 1896 di Swiss, Piaget adalah pakar psikologi yang sangat popular dalam sejarah perkembangan psikologi. Ayahnya adalah seorang profesor dalam bidang sastra abad pertengahan. Semasa kecilnya, ia tertarik pada alam dan senang mengamati kehidupan satwa di alam bebas, sehingga akhirnya ia berminat pada pelajaran biologi. Sejak usia 15 tahun ia telah dikenal luas karena menerbitkan karangan pertamanya tentang burung "Pipit Albino" pada majalah ilmu pengetahuan alam.

Pada usia 21 tahun, Piagt menyelesaikan pendidikan sarjana bidang biologi di Universitas Neuchatel dan 3 tahun kemudian Piaget menyelesaikan disertasi tentang moluska dan memperoleh gelar doctor filsafat. Tidak hanya sebatas itu Piaget memutuskan untuk mendalami psikologi di Zurich. Pada tahun 1919, ia meninggalkan Zurich dan pergi ke Paris, belajar di Universitas Sorbonne, terutama 
belajar epistemology. Pendalamnya tentang filsafat meyakinkan dirinnya bahwa perlunya pemikiran spekulasi murni dilengkapi dengan pendekatan ilmu pengetahuan yang faktual.

Karena kejeniusannya J. Piaget diangkat sebagai direktur penelitian di Institut Jean-Jacques Rousseu di Geneva. Di situ ia memperoleh kesempatan untuk mempelajari pemikiran anak. Hasil penelitiannya banyak dipublikasikan pada tahun 1923-1931 diantaranya "Bahasa dan pikiran anak-anak". Selama penelitian, Piaget semakin yakin akan adanya perbedaan antara proses pemikiran anak dengan orang dewasa. Piaget yakin bahwa anak bukan merupakan suatu tiruan (replika) dari orang dewasa. Anak bukan hanya berpikir kurang efisien dari orang dewasa, melainkan berpikir secara berbeda dengan orang dewasa. Itulah sebabnya mengapa Piaget yakin bahwa ada tahap perkembangan kognitif yang berbeda dari anak sampai menjadi dewasa. Piaget juga mencoba menemukan sebab-musabab perkembangan kognitif. Pada tahun 1920-1930, Piaget meneruskan penelitiannya dalam bidang perkembangan kognitif anak. Bersama dengan istrinya, Piaget meneliti ketiga anaknya sendiri yang lahir pada tahun 1925, 1927, dan 1931. Hasil pengamatan terhadap anak-anaknya ini dipublikasikan dalam The Original of Intelligence in Children dan the Consruction of Reality tentang tahap sensorimotor. Studinya tentang masa kanak-kanak meyakinkan Piaget bahwa pengertian dibentuk dari tindakan anak dan bukan dari bahasa anak.

Pada tahun 1950, Piaget banyak meneliti dan menulis tentang perkembangan inteligensi manusia. Piaget juga mangaplikasikan hasil penemuan psikologis tersebut dalam persoalan epistemology. Ditahun yang sama, Piaget mempublikasikan seri epistemology genetic. Buku ini merupakan sintesis pemikirannya akan beberapa aspek pengetahuan, termasuk matematika, fisika, psikologi, sosiologi, biologi, dan logika. Selaian dari pada itu begitu banyak karya-karya Piaget dalam dunia pendidikan tentang perkembngan kognitif hingga pada tanggal 16 September 1980 tokoh besar pencetus teori Genetic Epistemology yang terus dikenang dan di puja karena karya-karya jenius ini meninggal dunia di Geneva Swis.

\section{Pengertian “Genetic Epistemology"}

Epistemology atau teori pengetahuan berasal dari bahasa Yunani "episteme" yang artinya 'pengetahuan' (knowledge) dan "logos" yang artinya teori, atau pemikiran. Jadi epistemology dalam arti etimologisnya adalah teori pengetahuan atau pengetahuan tentang pengetahuan. Titik kajian epistemology adalah tentang fenomena pengetahuan dan jangkauan pengetahuan manusia dalam hubungannya dengan kodrati, struktur, corak dan bentuk hakikatnya. Adapun objek dan lingkup kajian epistemology mencakup (a) asal usul (genetika) pengetahuan (b) hubungan 
pemikiran dan pengetahuan (c) kedudukan pengalaman/emperia dan akal budi atau rasio dan produksi pengetahuan, d) hubungan antara pengetahuan dan keniscayaan, e) hubungan antara pengetahuan, kebenaran dan kepastian f) kemungkinan skeptisme universal yang muncul dari berbagai problematika ketidakpastian (uncertainty) dalam pengetahuan manusia. (Watloly, A. 2001).

Sejalan dengan itu dalam kamus besar bahasa Indonesia (1990) juga menerangkan secara harafiah arti epistimologi dan genetika sebagai berikut : epistemology adalah cabang ilmu filsafat tentang dasar-dasar dan batas-batas pengetahuan. genetik yaitu cabang biologi yang menerangkan sifat turun temurun. Menurut Driscoll (1994: 171) teori genetic epistemology sesungguhnya adalah pekerjaan pembangunan kognitif yang didasarkan pada "mengelaborasi sebuah teori pengetahuan, tentang bagaimana anak datang untuk mengenal dunia nya".

Teori genetik epistemology atau sering disebut teori Piaget didasarkan pada gagasan bahwa pengetahuan adalah akuisisi proses konstruksi diri secara terus menerus. Pengetahuan diciptakan dan kembali diciptakan sebagaimana anak berkembang dan terus berinteraksi dengan dunia sekitarnya. Pusat kajian untuk teori Piaget ini adalah gagasan bahwa anak-anak secara aktif memperoleh pengetahuan melalui tindakan mereka sendiri. (Driscoll, 1994).

Secara keseluruhan, tinjauan tentang perkembangan epistemology sebagai ilmu pengetahuan yang menjadi dasar Jean Piaget untuk melahirkan teori genetic epistemology ini kiranya menegaskan kembali sejumlah karakter filsafat yang mencakup sikap kritis karena epistemology menunjuk aktivitas kreatif budi, pikir yang terus menyejarah. Seperti kata John Minton yang dikutip Jenni Teichman dalam Ufie Josep, 2008: 143) bahwa dimana ada hasrat belajar begitu besar, disana pasti terjadi banyak perdebatan, debat gagasan dan debat tulisan, karena gagasan para pemikir yang baik termasuk sejarah epistemology tidak lain adalah pengetahuan yang berproses.

\section{Proses Belajar}

Kegiatan belajar merupakan suatu proses berpikir yang melibatkan kegiatan mental, terjadi penyusunan hubungan informasi-informasi yang diterima sehingga timbul suatu pemahaman dan penguasaan terhadap materi yang diberikan. Dengan adanya pemahaman dan penguasaan yang didapat setelah melalui proses belajar mengajar maka siswa telah memahami suatu perubahan dari yang tidak diketahui menjadi diketahui. Perubahan inilah yang disebut dengan hasil belajar.

Belajar atau learning sebagaimana yang dikemukakan oleh Kimble (1961), Gagne (1977), dan De Blok, (1982) dalam Dadang Supardan (2015: 3) bahwa pada hakikatnya menyangkut banyak bentuk, jenis dan fungsi serta kriterianya, setidaknya 
ada tiga kriteria dalam belajar, (a) belajar itu menyangkut perubahan perilaku, (b) hasil belajar itu bertahan relatif lama seiring dengan waktu, (c) belajar itu terjadi melalui pengalaman.

Sementara itu, menurut Crow and Crow dalam Apriyani (2008: 15) mengemukakan bahwa hasil belajar merupakan perolehan kebiasaan-kebiasaan, pengetahuan dan sikap. Pemerolehan ini termasuk suatu cara baru melakukan sesuatu dan cara mengatasi masalah pada situasi baru. Dengan demikian, hasil belajar merupakan suatu perubahan yang berupa perubahan tingkah laku, pengetahuan dan sikap yang diperoleh seseorang setelah melakukan proses kegiatan belajar.

Hasil belajar merupakan peristiwa yang bersifat internal dalam arti sesuatu yang terjadi di diri seseorang.Peristiwa tersebut dimulai dari adanya perubahan kognitif yang kemudian berpengaruh pada perilaku.Dengan demikian perilaku seseorang didasarkan pada tingkat pengetahuan terhadap sesuatu yang dipelajari yang kemudian dapat diketahui melalui tes, dan pada akhirnya muncul hasil belajar dalam bentuk nilai riel atau non riel.Hasil belajar merupakan hasil dari suatu interaksi tindak belajar dan tindak mengajar. Dari sisi guru, tindak mengajar diakhiri oleh evaluasi hasil belajar dan dari sisi siswa hasil belajar merupakan puncak proses belajar Jihad dan Haris (2008: 14-15). Hasil belajar merupakan kemampuan-kemampuan yang dimiliki oleh siswa berdasarkan pengalaman belajarnya.

Hasil belajar atau achievement merupakan realisasi atau pemekaran dari kecakapan-kecakapan potensial atau kapasitas yang dimiliki seseorang. Penguasaan hasil belajar oleh sesorang dilihat dari perilakunya, baik perilaku dalam bentuk penguasaan pengetahuan, keterampilan berpikir maupun keterampilan motorik. Pencapaian belajar atau hasil belajar diperoleh setelah dilaksanakannya suuatu program pengajaran.Penilaian atau evaluasi pencapaian hasil belajar merupakan langkah untuk mengetahui seberapa jauh tujuan kegiatan belajar mengajar (KBM) suatu bidang studi atau mata pelajaran telah dapat dicapai.Jadi hasil belajar yang dilihat dari tes hasil belajar berupa keterampilan pengetahuan integensi, kemampuan dan bakat individu yang diperoleh di sekolah biasanya dicerminkan dalam bentuk nilai-nilai tertentu.

Menurut Syaiful Bakri dalam Kristanti (2010: 45) hasil belajar adalah suatu kegiatan yang telah dilakukan atau dikerjakan baik secara individu maupun kelompok. Sedangkan Suharsimi Arikunto (2003: 21) berpendapat bahwa faktorfaktor yang mempengaruhi hasil belajar siswa dibedakan menjadi dua jenis yaitu: faktor-faktor yang bersumber dari dalam diri manusia dapat diklasifikasikan menjadi dua, yakni faktor biologis dan faktor psiklogis. Yang dapat dikatagorikan factor biologis antara lain: usia, kematangan, dan kesehatan. Sedangkan yang dapat dikatagorikan sebagai factor psikologis adalah kelelahan, suasana hati, motivasi, 
minat dan kebiasaan belajar. Faktor-faktor yang bersumber dari luar diri manusia dapat diklasifikasikan menjadi dua juga, yakni faktor manusia (human) dan faktor non manusia seperti alam, benda, hewan, dan lingkungan fisik.

Hasil belajar menurut taksonomi Bloom seperti yang dikutip oleh Santrock (2004: 468-470) terdiri dari 3 ranah yaitu kognitif, afektif, dan psikomotorik. Penelitian ini mengukur hasil belajar pada tingkat kognitif dan afektif. Tipe belajar hasil kognitif meliputi tipe belajar hasil pengetahuan hafalan (knowledge), tipe hasil belajar pemahaman (comprehention), tipe hasil belajar penerapan (aplicationi), tipe belajar hasil analisis, dan tipe belajar evaluasi. Tipe hasil belajar afektif berkenaan dengan sikap dan nilai. Sedangkan tipe hasil belajar bidang psikomotorik tampak dalam bentuk keterampilan (skill) dan kemampuan bertindak individu (perseorangan.

\section{Ranah Kognitif}

Ranah kognitif berhubungan dengan kemampuan berpikir, mengetahui, dan memecahkan masalah seperti pengetahuan komprehensif, aplikatif, sintesis, analisis, dan kreasi.Hal ini dipertegas oleh Santrock (2004: 471) yang menyebutkan bahwa ranah kognitif menyangkut hal- hal yang berhubungan dengan ingatan, atau pengenalan terhadap pengetahuan dan informasi, serta pengembangan intelektual. Ranah kognitif terdiiri dari 6 domain yaitu: pengetahuan, pemahaman, aplikasi, analisis, sintesis, dan kreasi. Dengan demikian dapat ditarik kesimpulan bahwa kemampuan kognitif adalah kemampuan yang dimiliki oleh siswa terkait dengan berpikir atau kemampuan intelektual.

Kemampuan kognitif terdiri dari 6 domain pengetahuan, pemahaman, aplikasi, analisis, sintesis, dan kreasi. Menurut Dimyati dan Mujiono (2006: 27) keenam jenis domain ini bersifat hierarkhis, artinya perilaku yang terendah merupakan perilaku yang harus dimiliki terlebih dahulu sebelum mempelajari perilaku yang lebih tinggi. Misalnya, untuk dapat menganalisis siswa harus memiliki pengetahuan, pemahaman, dan penerapan tertentu.

\section{Ranah Afektif}

Ranah afektif berhubungan dengan sikap, nilai, minat, dan apresiasi.Singkatnya ranah afektif sangat berhubungan dengan respons emosional yang menurut Krathwohl, Bloom, dan Masia dalam Santrock (2004: 469) terdiri dari :

a. Menerima, merupakan kemampuan yang berupa perhatian terhadap situasi secara pasif yang meningkat secara aktif.

b. Merespon, merupakan kesengajaan untuk menanggapai stimulan dan merasa terikat secara aktif memperhatikan. Aspek yang diukur dalam penelitian ini 
adalah yang terkait dengan merespon. Dalam hal ini aspek kerajinan dan kemauan siswa untuk bekerja sama selama diskusi kelompok dan presentasi.

c. Menilai, merupakan kemampuan untuk menilai gejala atau kegiatan sehingga dengan sengaja merespon lebih lanjut untuk mencari dan menemukan jalan atas apa yang sedang terjadi. Aspek yang dinilai dalam penelitian ini adalah kejujuran selama mengerjakan soal ulangan harian.

d. Mengorganisasi, merupakan kemampuan untuk membentuk suatu sistem nilai bagi dirinya berdasarkan nilai-nilai yang dipercaya.

e. Karakterisasi, merupakan kemampuan untuk mengkonseptualisasikan masingmasing nilai waktu merespon dengan jalan memfasilitasi dan membuat pertimbangan-pertimbangan.

\section{Ranah Psikomotorik}

Simpson (1966) dalam Degeng (1992: 84-85) mengembangkan ranah psikomotorik menjadi 5.Mulai dari tingkat terendah yakni persepsi, samapi pada tingkat penguasaan keterampilan yang terpola dan keaslian. Klasifikasi ranah tersebut adalah sebagai berikut:

a. Persepsi: proses munculnya kesadaran tentang adanya objek dan karakteristikkarakteristiknya melalui indera.

b. Kesiapan: pada tingkat ini, siswa siap untuk melakukan suatu tindakan baik secara mental, fisik, atau emosional.

c. Respons Terbimbing: siswa melakukan tindakan dengan mengikuti suatu model. Ini dapat dilakukan dengan meniru model dan coba-gagal sampai tindakan benar dikuasai.

d. Mekanisme: pada tingkat ini, siswa telah mencapai tingkat kepercayaan tertentu dalam menampilkan keterampilan yang dipelajari.

e. Respon Terpola: pada tingkat ini, siswa telah mencapai tingkat keterampilan yang tinggi.

f. Penyesuaian/Keaslian: pada tingkat ini siswa telah begitu terampil sehingga ia dapat menyesuaikan tindakannya untuk situasi-situasi yang menuntut persyaratan tertentu.

\section{PEMBAHASAN}

\section{Gambaran Umum Teori Genetik Epistemology}

Menurut Jean Piaget, epistemologi genetik "adalah upaya untuk menjelaskan pengetahuan terlebih khusus pengetahuan ilmiah". Bidang ini didefinisikan sebagai studi tentang perkembangan anak sebagai alat untuk menjawab pertanyaanpertanyaan epistemologis. Pada tahun 1920, Piaget bekerja bersama Dr.Theophile 
Simon di laboratorium Binet di Paris dengan tugas mengembangkan tes penalaran yang kemudian diujikan. Dari hasil uji yang diperolehnya, Piaget menyimpulkan bahwa perbedaan jawaban yang ada disebabkan oleh perbedaan intelegensi peserta.

Berdasarkan pengalaman membuat tes tersebut, Piaget mendapatkan tiga pemikiran penting yang mempengaruhi berpikir dikemudian hari. Pertama, Piaget melihat bahwa anak yang berbeda umur menggunakan cara berpikir yang bebeda. Inilah yang menurut Piaget tahap-tahap perkembangan kognitif anak. Kedua, metode klinik digunakannya untuk mengorek pemikiran anak secara lebih mendalam. Metode inilah yang dikembangkan Piaget dalam studinya tentang perkembangan kognitif anak. Ketiga, Piaget berpikir bahwa pemikiran logika abstrak mungkin relevan untuk mememahami pemikiran anak.

Menurutnya, operasi-operasi logika yang ada dalam pemikiran deduksi berkaitan dengan struktur mental tertentu dalam diri anak. Ia mencoba untuk menemukan bagaimana pemikiran sangat berkaitan dengan logika. Ciri pemikiran deduksi logis (abstrak dan hipotesis) ini menjadi salah satu ukuran tertinggi Piaget dalam menentukan tahap-tahap perkembangan kognitif anak.

Piaget mengembangkan teori perkembangan kognitif yang cukup dominan selama beberapa dekade. Dalam teorinya Piaget membahas pandangannya tentang bagaimana anak belajar. Menurut Jean Piaget, dasar dari belajar adalah aktivitas anak bila ia berinteraksi dengan lingkungan sosial dan lingkungan fisiknya. Pertumbuhan anak merupakan suatu proses social artinya bahwa anak berinteraksi dengan lingkungan fisiknya bukan hanya sebagai suatu individu terikat, tetapi sebagai bagian dari kelompok sosial. Akibatnya lingkungan sosialnya berada diantara anak dengan lingkungan fisiknya olehnya itu interaksi anak dengan orang lain sangat penting guna pengembangan pandangannya terhadap alam. Melalui pertukaran ide-ide, gagasan dengan orang lain, seorang anak yang tadinya memiliki pandangan subyektif terhadap sesuatu yang diamatinya akan berubah menjadi pandangan obyektif.

Konsep yang eksis dalam pikiran individu dipakai untuk mengorganisasikan dan menginterprestasikan informasi itulah yang oleh Piaget menyebutnya “skema”. Minat Piaget terhadap skema difokuskan pada bagaimana anak memahami dunianya, anakanak secara kognitif mengorganisasikan pengalaman mereka. Menurut Piaget ada dua proses yang bertanggungjawab atas cara anak menggunakan dan mengadaptasi skema mereka yaitu asimilasi dan akomodasi (Piaget dalam John W. Santrock, 2008: 46). Asimilasi adalah proses kognitif dimana seseorang mengintegrasikan persepsi, konsep ataupun pengalaman baru ke dalam skema atau pola yang sudah ada dalam pikirannya. Asimilasi dipandang sebagai suatu proses kognitif yang menempatkan dan mengklasifikasikan kejadian atau rangsangan baru dalam skema yang telah ada. Asimilasi tidak akan menyebabkan perubahan/pergantian skemata melainkan 
perkembangan skemata. Asimilasi merupakan salah satu proses individu dalam mengadaptasikan dan mengorganisasikan diri dengan lingkungan baru. Akomodasi. Dalam menghadapi rangsangan atau pengalaman baru seseorang tidak dapat mengasimilasikan pengalaman yang baru dengan schemata yang telah dipunyai. Pengalaman yang baru itu bisa jadi sama sekali tidak cocok dengan skema yang telah ada. Dalam keadaan demikian orang akan mengadakan akomodasi.

Akomodasi tejadi untuk membentuk skema baru yang cocok dengan rangsangan yang baru atau memodifikasi skema yang telah ada sehingga cocok dengan rangsangan itu. Bagi Piaget adaptasi merupakan suatu keseimbangan antara asimilasi dan akomodasi. Bila dalam proses asimilasi seseorang tidak dapat mengadakan adaptasi terhadap lingkungannya maka terjadilah ketidakseimbangan (disequilibrium). Akibat ketidakseimbangan itu maka terjadilah akomodasi dan struktur kognitif yang ada akan mengalami perubahan atau munculnya struktur yang baru. Pertumbuhan intelektual ini merupakan proses terus menerus tentang keadaan ketidakseimbangan dan keadaan seimbang (disequilibrium-equilibrium).

\section{Beberapa Konsep Inti Dari Teori Genetik Epistemology Jean Piaget.}

Konsep-konsep dimaksud perlu diketahui dan kemudian di mengerti agar lebih mempermudah pemahaman kita terhadap teori perkembangan kognitif yang dikembangkan Piaget, yaitu :

\section{a. Intelegensi}

Piaget mengartikan intelegensi secara lebih luas, juga tidak mendefinisikan secara ketat. Piaget memberikan definisi umum yang lebih mengungkap orientasi biologis. Menurutnya, intelegensi adalah suatu bentuk ekuilibrium kearah mana semua struktur yang menghasilkan persepsi, kebiasaan, dan mekanisme sensiomotor diarahkan. (Piaget dalam P. Suparno, 2001: 19).

\section{b. Organisasi}

Organisasi adalah suatu tendensi yang umum untuk semua bentuk kehidupan guna mengintegrasikan struktur, baik yang psikis ataupun fisiologis dalam suatu sistem yang lebih tinggi.

\section{c. Skema}

Skema adalah suatu struktur mental seseorang dimana dia secara intelektual beradaptasi dengan lingkungan sekitarnya. Skema akan beradaptasi dan berubah selama perkembangan kognitif seseorang.

d. Asimilasi

Asimilasi adalah proses kognitif dimana seseorang mengintegrasikan persepsi, konsep atau pengalaman baru kedalam skema atau pola yang sudah ada dalam pikirannya. 


\section{e. Akomodasi}

Akomodasi adalah pembentukan skema baru atau mengubah skema lama sehingga cocok dengan rangsangan yang baru, atau memodifikasi skema yang ada sehingga cocok dengan rangsangan yang ada.

\section{f. Ekuilibrasi}

Ekuilibrasi adalah keseimbangan antara asimilasi dan akomodasi sedangkan diskuilibrasi adalah keadaan dimana tidak seimbangnya antara proses asimilasi dan akomodasi, ekuilibrasi dapat membuat seseorang menyatukan pengalaman luar dengan struktur dalamnya.

\section{Tahap Perkembangan Intelektual Anak}

Menurut Piaget, tahap perkembangan intelektual anak secara kronologis terjadi 4 tahap. Keempat tahap dimaksud adalah sebagai berikut :

\section{a. Tahap Sensorimotor : Umur 0-2 Tahun}

Ciri pokok yang dialami anak pada tahapan ini adalah anak mengalami perkembangan dunianya melalui gerak dan inderanya serta mempelajari obyek. Perkembangan kognitif terjadi pada waktu bayi lahir sampai berumur 2 tahun. Tahap ini oleh Piaget disebut tahap sensorimotor. Pada tahap sensorimotor, intelegensi anak lebih didasarkan pada tindakan inderawi pada lingkungannya, seperti melihat, meraba, menjamak, mendengar dan lain-lain. Tahap sensorimotor ini pula, gagasan anak mengenai suatu benda berkembang dari "belum mempunyai gagasan" menjadi "sudah mempunyai gagasan". Menurut Piaget, mekanisme perkembangan sensorimotor ini menggunakan proses asimilasi dan akomodasi, karena adanya masukan, rangsangan, atau kontak dengan pengalaman dan situasi yang baru.

Sensorimotor dibagi menjadi enam tahapan/periode yaitu :

\section{- Periode 1 : Refleks (Umur 0-1 Bulan)}

Periode refleks adalah tahap paling awal sensorimotor. Pada periode ini, tingkah laku bayi kebanyak bersifat refleks, spontan, tidak disengaja. Gerakan seorang bayi didasarkan atas adanya rangsangan dari luar dirinya yang ditanggapi secara refleks.

\section{- Periode 2 : Kebiasaan (Umur 1-4 Bulan)}

Pada periode ini, bayi memulai membentuk kebiasan-kebiasaan awal. Kebiasaan itu dilakukan secara terus menerus dan berulang-ulang. Gerakan refleks yang dibuat oleh seorang bayi diasimilasikan dengan skema yang telah dimiliki sehingga menjadi kebiasaan dan menghasilkan sesuatu. Pada masa ini, seorang bayi mulai membedakan benda-benda, mulai 
menggunakan indra pendengaran dan memulai menggerakan matanya mengikuti benda.

- Periode 3 : Reproduksi Kejadian Yang Menarik (Umur 4-8 Bulan)

Periode ini, seorang bayi mulai menjamah dan memanipulasi objek apapun yang ada di sekitarnya. Pada masa ini tingkah laku seorang bayi semakin berorientasi pada objek dan kejadian di luar tubuhnya sendiri dan seorang bayi menciptakan kembali kejadian kejadian yang menarik baginya. Piaget mengamati bahwa bila seorang anak dihadapkan pada sebuah benda yang dikenal, seringkali hanya menunjukkan reaksi singkat dan tidak mau memperhatikan agak lama. Oleh Piaget, ini diartikan sebagai suatu "pengiaan" akan arti benda itu seakan ia mengetahuinya.

- Periode 4 : Koordinasi Skemata (Umur 8-12 Bulan)

Pada periode ini, seorang bayi mulai membedakan antara sarana dan hasil tindakannya. Bayi mulai mempunyai kemampuan untuk menyatukan tingkah laku yang sebelumnya telah diperoleh untuk mencapai tujuan tertentu. Pada periode ini, konsep tentang tetapnya (permanensi) suatu benda mulai terbentuk. Faktanya bahwa pada tahap ini seorang bayi dapat mencari benda yang tersembunyi ini berarti ia mulai mempunyai konsep tentang ruang.

- Periode 5 : Eksperimen (Umur 12-18 Bulan)

Anak pada periode ini mulai memperkembangkan cara-cara baru dalam mewujudkan keinginannya, konkritnya pada masa ini anak mulai mencobacoba untuk menemukan cara yang baru dengan mengembangkan skema yang ada. Pada periode ini, anak lebih mengamati benda-benda disekitarnya dan mengamati bagaimana benda-benda itu bertingkah laku dalam situasi yang baru. Menurut Piaget, tingkah anak ini menjadi intelegensi sewaktu anak itu menemukan kemampuan untuk memecahkan persoalan yang baru. Pada periode ini pula, konsep anak terhadap benda mulai maju dan lengkap, anak mulai mempertimbangkan organisasi perpindahan semua benda-benda itu secara serentak bila dapat dilihat.

\section{- Periode Refresentasi (Umur 18-24 Bulan)}

Tahapan ini adalah tahapan terakhir pada fase intelegensi sensorimotor. Pada periode ini, secara mental seorang anak mulai dapat menggambarkan suatu benda dan kejadian, kemudian dapat menyelesaikan persoalan dengan gambaran tersebut. Konsep benda pada tahap ini sudah maju, refresentasi ini membiarkan anak untuk mencari dan menemukan objek-objek yang tersembunyi. Sikap anak yang sudah pada tahap ini adalah sebagai berikut:

Berfikir melalui perbuatan atau gerakan. 
* Perkembangan fisik anak dimulai dari gerakan reflex sampai dapat berjalan dan bicara.

Mulai belajar untuk mengkoordinasi pikiran/akal dan geraknya.

Kecenderungan intuitif egosentris, tidak rasional dan tidak logis sangat besar.

\section{b. Tahap Pra Operasional : Umur 2-7 Tahun}

Ciri pokok perkembangannya adalah penggunaan symbol/bahasa tanda dan konsep intuitif.

Istilah "operasi" di sini adalah suatu proses berfikir logik, dan merupakan aktivitas sensorimotor. Dalam tahap ini anak sangat egosentris, mereka sulit menerima pendapat orang lain. Anak percaya bahwa apa yang mereka pikirkan dan alami juga menjadi pikiran dan pengalaman orang lain. Tahap pra operasional ini dapat dibedakan atas dua bagian. Pertama, tahap pra konseptual (2-4 tahun), dimana representasi suatu objek dinyatakan dengan bahasa, gambar dan permainan khayalan. Kedua, tahap intuitif (4-7 tahun). Pada tahap ini representasi suatu objek didasarkan pada persepsi pengalaman sendiri, tidak kepada penalaran.

Karakteristik anak pada tahap ini adalah sebagai berikut:

- Anak dapat mengaitkan pengalaman yang ada di lingkungan bermainnya dengan pengalaman pribadinya, dan karenanya dia menjadi egois. Anak tidak rela bila barang miliknya dipegang oleh orang lain.

- Anak belum memiliki kemampuan untuk memecahkan masalah- masalah yang membutuhkan pemikiran "yang dapat dibalik (reversible)." Pikiran mereka masih bersifat irreversible.

- Anak belum mampu melihat dua aspek dari satu objek atau situasi sekaligus, dan belum mampu bernalar secara individu dan deduktif.

- Anak bernalar secara transduktif (dari khusus ke khusus). Kadang- kadang anak seperti berbohong karena anak belum mampu memisahkan kejadian sebenarnya dengan imajinasi mereka.

- Anak belum memiliki konsep kekekalan (kuantitas, materi, luas, berat dan isi).

- Menjelang akhir tahap ini, anak mampu memberi alasan mengenai apa yang mereka percayai. Anak dapat mengklasifikasikan objek ke dalam kelompok yang hanya mempunyai satu sifat tertentu dan telah mulai mengerti konsep yang konkrit.

\section{c. Tahap Operasi Kongkret : Umur 7-11/12 Tahun}

Ciri pokok perkembangannya anak mulai berpikir secara logis tentang kejadiankejadian konkret. 
Pada tahap operasi konkret (concrete operations) anak-anak dicirikan dengan perkembangan sistem pemikiran berdasarkan aturan-aturan tertentu yang logis. Anak sudah dapat memperkembangkan operasi-operasi logis, operasi itu bersifat reversible, artinya dapat dimengerti dalam dua arah, yaitu suatu pemikiran yang dapat dikemblikan kepada awalnya lagi. Tahap opersi konkret dapat ditandai dengan adanya sistem operasi berdasarkan apa-apa yang kelihatan nyata/konkret. Ciri-ciri operasi konkret yang lain, yaitu:

- Adaptasi dengan gambaran yang menyeluruh

- Melihat dari berbagai macam segi

- Seriasi

- Klasifikasi

- Bilangan

- Ruang, waktu, dan kecepatan

- Penalaran

\section{d. Tahap Operasi Formal : Umur 11/12 ke Atas}

Ciri pokok perkembangannya adalah hipotesis, abstrak, dan logis

Tahap operasi formal (formal operations) merupakan tahap terakhir dalam perkembangan kognitif Piaget. Dalam tahap ini, seorang anak remaja sudah dapat berpikir logis, teoritis dan formal berdasarkan hipotesis, serta mampu membuat kesimpulan dari apa yang diamatinya. Sesuatu yang abstrak sifatnya dia sudah bias mengerti. Sifat dasar pada tahap operasi formal adalah anak sudah mampu berpikiran deduktif hipotesis, induktif sintifik dan abstrak reflektif.

- Pemikiran Deduktif Hipotesis

Pemikiran deduktif adalah pemikiran yang menarik kesimpulan yang spesifik dari sesuatu yang umum. Dalam pemikiran anak remaja, Piaget dapat mendeteksi adaanya pemikiran yang logis, meskipun para remaja sendiri pada kenyataannya tidak tahu atau belum menyadari bahwa cara berpikir mereka itu logis. Dengan kata lain, model logis itu lebih merupakan hasil kesimpulan Piaget dalam menafsirkan ungkapan remaja, terlepas dari apakah para remaja sendiri tahu atau tidak.

- Pemikiran Induktif Sintifik

Pemikiran induktif adalah pengambilan kesimpulan yang lebih umum berdasarkan kejadian-kejadian yang khusus. Pemikiran ini disebut juga dengan metode ilmiah. Pada tahap pemikiran ini, anak sudah mulai dapat membuat hipotesis, menentukan eksperimen, menentukan variabel control, mencatat hasil, dan menarik kesimpulan. 


\section{- Pemikiran Abstraksi Reflektif}

Menurut Piaget, pemikiran analogi dapat juga diklasifikasikan sebagai abstraksi reflektif karena pemikiran itu tidak dapat disimpulkan dari pengalaman.

\section{Penerapan Teori Genetik Epistemologi Dalam Pembelajaran}

Teori genetik epistemology yang dikembangkan oleh Jean Piaget telah membawa dampak besar terhadap teori dan praktik pendidikan diseluruh dunia seperti yang dikatakan oleh Case dalam Robert E. Slavin, (2008: 57) bahwa teori kognitif atau teori pengetahuan (genetic epistemology) yang dikembangkan oleh Jean Piaget memusatkan perhatian pada gagasan pendidikan yang tepat untuk pendidikan, suatu pendidikan dengan lingkungan, kurikulum, bahan ajar dan pengajaran yang sesuai dengan siswa dari sudut kemampuan fisik dan kognitif serta kebutuhan social, ekonomi siswa".

Jean Piaget sangat mempengaruhi bidang pendidikan, terlebih pendidikan kognitif anak. Tahap-tahap pemikiran Piaget mewarnai struktur berpikir para pendidik dalam menyusun kurikulum, memilih metode pengajaran dan juga memilih bahan ajar bagi anak-anak di sekolah-sekolah. Sejumlah praktisi pendidikan telah merasakan bahwa pendekatan kognitif oleh Piaget yang menekankan persepsi dan keyakinan manusia dalam hal ini anak memiliki kelebihan tertentu dari pada pendekatan koneksionis yang menekankan kebiasaan.

Teori genetik epistemology atau teori Piaget memfokuskan pada proses pemikiran anak-anak bukan hanya hasilnya. Dengan demikian guru dituntut untuk memahami cara atau proses yang digunakan oleh siswa untuk sampai pada menjawab pertanyaan-pertanyaan yang diberikan. Karena menurut Piaget pengalaman pembelajaran yang tepat didasarkan pada tingkat keberfungsian kognitif anak-anak, untuk itu guru harus menghargai metode yang digunakan oleh anak-anak sampai pada kesimpulan tertentu. (Robert E. Slavin, 2008; 57)

Beberapa hal penting yang patut diperhatikan guru guna menerapkan teori Piaget pada pendidikan anak adalah: 1) Gunakan pendekatan konstruktivis. Disini Piaget menekankan bahwa anak-anak akan belajar dengan lebih baik jika mereka aktif dan mencari solusi sendiri. Artinya bahwa untuk semua mata pelajaran hendaknya murid lebih banyak diajari untuk memikirkan, mendiskusikan dan menemukan sendiri jawaban atas pertanyaan/masalah yang diajukan oleh guru bukan dengan menyalin atau mencatat materi yang disampaikan oleh guru. 2) Fasilitas belajar. Guru yang efektif harus merancang situasi yang membuat belajar dengan bertindak (learning by doing). Guru dituntut untuk mendengar, mengamati, kemudian mengajukan pertanyaan yang relevan untuk merangsang agar siswa berpikir dan menemukan 
jawaban serta mampu menjelaskan pikiran mereka. 3) Pertimbangkan pengetahuan dan tingkat pemikiran anak. Murid datang ke sekolah tidak dengan kepala kosong, mereka punya banyak gagasan tentang dunia, mereka punya konsep tentang banyak hal. 4) Gunakan penilaian terus-menerus. Yang dipakai untuk mengevaluasi kemajuan siswa adalah bagaimana strategi pemikiran, daya nalar siswa untuk menyelesaikan pertanyaan secara lisan dalam proses diskusi maupun penjelasan tertulis. 5) Pastikan bahwa materi yang disiapkan akan meransang siswa untuk berpikir dan mengajukan pertanyaan. Disini guru dituntut untuk menyiapkan berbagai alat bantu yang sesuai dengan topik yang hendak didiskusikan misalnya guru menyiapkan seekor kumbang kecil kemudian menyuruh siswa untuk mengamati dan mendeskripsikanya. Keesokan hari berikan lagi kumbang yang besar dan ini prose yang akan membuat anak-anak terkejut dan mendorong mereka untuk berpikir lagi. 6) Ketika akan mengajar topik yang kompleks, maka gunakan alat bantu visual. Misalnya saat mengajar topik pemhasan tentang demokrasi maka guru harus menyiapkan rekaman video yang mengilustrasikan konsep tersebut.

Maha karya teori Jean Piaget dapat diimplementasikan pada proses pembelajaran disekolah sesuai dengan teori perkembangannya itu sendiri. Implementasi pada pembelajaran yang akan disajikan ini hanya merupakan contoh bagaimana teori kognitif diaplikasikan dalam pembelajaran menurut kesimpulan saya. Hal yang sangat diharapkan dalam proses pembelajaran sesuai teori kognitif ini adalah kesesuaian pemilihan model/metode serta pendekatan dalam pembelajaran terhadap materi.

Aplikasi atau implementasi teori Piaget dalam pembelajaran sesuai tahap perkembangan kognitif anak sesuai usia sekolah adalah sebagai berikut :

$\begin{array}{lll}\text { Materi } & : \text { Pancasila } \\ \text { Sub Materi } & : \text { Isi } \\ & : \text { Lambang Negara } \\ & : \text { Dasar Negara } \\ & : \text { Tujuan } \\ & : \text { Manfaat }\end{array}$

Aplikasi pembelajaran teori Piaget pada tingkat Taman Kanak-Kanak (TK)

- Anak-anak hanya bisa diperkenalkan Pancasila

- Anak baru diperkenalkan dengan burung garuda sebagai Lambang Negara

- Anak hanya mampu untuk melihat gambar/mulai melafalkan isi Pancasila

Artinya bahwa anak usia pada sekolah Taman Kanak-Kanak dikategorikan masuk tahap pra operasional oleh Piaget. Aplikasi pembelajaran teori Piaget pada tingkat Sekolah Dasar (SD) :

- Anak sudah diperkenalkan dan menyebutkan isi Pancasila

- Anak juga harus mengenal burung Garuda sebagai Lambang Negara 
- Anak harus dituntun untuk menemukan sendiri pemahamannya tentang Pancasila dan Burung Garuda

Anak pada Sekolah Dasar (SD) diaplikasikan teori pembelajaran, dua tahapan sesuai pengklasifikasian teori Piaget yaitu Pra Operasional terutama pada kelas I-II dan akan dilanjutkan pada kelas berikutnya dengan pendekatan tahapan Operasi Konkrit sesuai teori perkembangan kognitif Piaget. Aplikasi pembelajaran teori Piaget pada tingkat SMP/SMU

- Anak diajarkan untuk mengetahui isi Pancasila serta dapat menyebutkannya

- Setiap sila yang ada pada pancasila itu anak-anak bisa menemukan maknanya

- Untuk anak-anak Sekolah Menengah Umum (SMU) memperdalam dan mengkaji unsur-unsur, makna sila-sila pada isi Pancasila. Anak-anak SMU sudah bisa sampai pada tingkat penalaran oleh karena pengalamannya sendiri.

Anak sekolah SMP/SMU sudah berada pada tahap operasi formal sesuai dengan tingkat perkembangan kognitif Piaget. Aplikasi pembelajaran teori Piaget pada tingkat Perguruan Tinggi/PT

- Anak-anak mahasiswa sudah lebih mendalami makna, arti serta menemukan sendiri cara mengamalkan semangat dari Pancasila itu.

- Mampu memberikan pandangan konstruktif yang lahir dari pengalamannya sendiri atau hasil kajiannya.

Pada bagian ini anak-anak siswa/mahasiswa harus mampu menggunakan tahap yang oleh teori kognitif Piaget adalah tahapan deduktif, induktif, hipotesis dan logis. Teori perkembangannya masih menggunakan tahapan operasi formal sebagaimana teori kognitif Piaget.

\section{KESIMPULAN}

Teori genetic epistemology yang dikembangkan oleh Jean Piaget atau sering dikenal dengan teori Piaget telah merambah di senatero jagat raya. Kosepnya tentang asimilasi, akomodasi, egosentrisme dan hipotesis deduktif yang menempatkan anak sebagai pemikir aktif kronstruktif masih bertahan sampai saat ini. Sebagaimana lasimnya sebuah pendapat atau teori pastilah tidak luput dari debat atau kritik yang ilmiah sifatnya, kritik-kritik dimaksud tidak untuk merubah konsep yang telah ada namun lebih pada melengkapi apa yang sudah ada dengan berbagai pendekatan.Aliran neo-Piagetian misalnya adalah kelompok ahli psikologi perkembangan yang terus melakukan penelitian dan mengkritik teori Piaget dalam konteks untuk perbaikan, mereka percaya bahwa teori Piaget ada yang benar tetapi teorinya perlu direvisi terutama pada bagaimana proses informasi melalui perhatian memori dan strategi. 
Kritik terus dilantunkan oleh berbagai ilmuan yang menaruh perhatian besar bagi perkembangan pendidikan, khsusunya perkembangan kognitif anak. Dengan terus melakukan penelitian-penelitian mereka mempertanyakan konsep-konsep penting yang disampaikan oleh Piaget dalam menemukan teorinya seperti yang disumpulkan oleh Flavell, Miller, Wertsch (John W. Santrock, 2008; 58) tentang estimasi terhadap kompetensi anak di level perkembangan yang berbeda-beda, tentang tahap-tahap perkembangan, tentang pelatihan anak untuk melakukan penalaran pada level perkembangan yang berbeda-beda, tentang tahap-tahap perkembangan, tentang pelatihan anak untuk melakukan penalaran pada level yang lebih tingi, tentang kultur dan pendidikan.

Merujuk pada apa yag telah saya bentangkan diatas maka menurut saya teori ini lebih banyak memberikan kesempatan kepada anak untuk menemukan cara/jalan secara mandiri dalam menyelesaikan pertanyaan-pertanyaan, guru hanyalah menuntun, guru tidak mempunyai peran lebih. Ini mengandung makna bahwa sistim yang dikembangkan tidaklah dua arah (timbal balik) antara guru dan siswa namun lebih pada searah. Titik fokusnya adalah anak bukan guru, sementara guru dan siswa adalah dua sisi yang saling melengkapi, saling berinteraksi aktif untuk kepentingan pembelajaran di kelas.

Namun sampai saat ini, Teori Piaget masih eksis dan digunakan kebanyakan orang. Piaget masih dikenang dari masa ke masa karena Piaget menemukan hakikat yang mendasar dalam proses perkembangan dan pembeljaran anak. Meskipun latar belakang Piaget bukan dari kalangan psikolog namun pemikiran yang jenius itu telah membawa implikasi penting bagi pendidikan. Prinsip-prinsip Piaget dimasukan dalam kurikulum dan dalam praktek pengajaran yang efektif, konsep-konsep yang dipengaruhinya seperti konstruktivisme, kognitif dan pengajaran yang sesuai dengan perkembangan anak, lingkungan alam dan sebagainya masih menjadi idola. Konsep Piaget sangat berperan penting juga dalam mereformasi pendidikan. Dari apa yang dipikirkan oleh Piaget kemudian melahirkan karya besar yang belum tergantikan sampai saat ini adalah sebuah goresan sejarah dalam dunia pendidikan. Tidak ada yang lebih diperlukan untuk seorang sains dari pada sejarah karena sejarah adalah guru terbaik bagi seorang sarjana ilmiah.

\section{DAFTAR PUSTAKA}

Apriyani, D. (2008). Peningkatan Hasil Belajar Biologi Siswa Dengan Menggunakan Pendekatan Interaktif Pada Konsep Sistem Pernapasan Pada Manusia. (Online), (http://Getskripsi.Com/2008/11/26, diakses, 26 Januari 2009).

Arikunto, Suharsimi. 2010. Penelitian Tindakan Kelas. Jakarta: Bumi Aksara. 
Creswell John W., 2010, Research Design: Qualitative, Quantitative, and Mixed Methods Approaches, $3^{\text {th }}$, terjemahan Achmad Fawaid, Yogyakarta.

Dadang Supardan. (2015). Teori-teori Belajar dan Pembelajaran. Bandung: Yayasan Rahardja.

Depertemen Pendidikan Nasional.2003a. Kurikulum Berbasis Kompetensi Kebijakan Umum (Buku 1-A). Departemen Pendidikan Nasional:Jakarta.

Dimyati dan Mudjiano. (2006). Belajar dan Pembelajaran. Jakarta: Rineka Cipta.

Driscoll, M. P. (1994). Psikologi Belajar untuk Instruksi. Boston: Allyn dan Bacon.

John W. Santrcok. 2004. Psikologi Pendidikan. Edisi II, 2008. Diterjehmakan oleh Triwibowo B.S. Jakarta: Prenada Media Group.

Josep Ufie. 2008. Traktat Filsafat Ilmu Pengetahuan. Jakarta: Cahaya Pineleng.

Kristanti, Wulan. 2010. Pengaruh Metode Pembelajaran Kontekstual Terhadap Hasil Belajar IPS Geografi Kelas VIII SMPN 18 Balikpapan Ditinjau Dari Motivasi Belajar Siswa Tahun Pelajaran 2009/2010, (Online), (www.pustaka.uns.ac.id, diakses 27 Februari 2011).

Paul Suparno. 2003. Teori Perkembangan Kognitif Jean Piaget. Yogyakarta: Kanisius.

Robert, E. Salvin. 2008. Psikologi Pendidikan.Edisi VIII, Jilid I. Diterjemahkan oleh Marianto Somosir dkk. Jakarta: PT. Indeks.

Tim Penyusun. Kamus Besar Bahasa Indonesia. 1990. Jakarta: Balai Pustaka

Watloly, A. 2001. Tanggung Jawab Pengetahuan, Mempertimbangkan Epistemology secara Kultural. Yogyakarta, Kanisius.

[Online Tersedia]. http://kadalmesirbersaudara.wordpress.com/2010/05/08/ pandangan- filsafat/ [diaskes 13 September 2011]. 